\title{
Faktor-Faktor Penyebab Kejadian Low Back Pain pada Pekerja Kantoran: Systematic Review
}

\author{
Putri Yasmin Rahmadiani, Neva Azzahra, Riza Andini Anggraini, Veronica Christie \\ Guesteva, Laura Patrycia Maudi \\ Program Studi Kesehatan Masyarakat Program Sarjana, Fakultas Ilmu Kesehatan, Universitas \\ Pembangunan Nasional Veteran Jakarta
}

\begin{abstract}
Abstrak
Latar Belakang: Saraf tepi pinggang bagian bawah sering mengalami masalah kesehatan yang saat ini lebih dikenal sebagai Low Back Pain (LBP). Penyakit ini sangat umum terjadi dan menjadi salah satu faktor utama yang berpengaruh dalam kualitas kinerja dan kesejahteraan kerja. Penyebab Low Back Pain (LBP) yang paling sering adalah duduk terlalu lama, sikap duduk yang salah, dan aktivitas yang berlebihan. Tujuan penelitian ini adalah untuk mengetahui dan memahami faktor-faktor besar yang menyebabkan terjadinya Low Back Pain di tempat kerja kantoran.

Metode: Kajian ini diolah melalui proses sistematik yang tentu disesuaikan dengan tahapan Preferred Reporting Items for Systematic Review (PRISMA). Google Scholar digunakan karena kemudahan dalam mengakses juga banyaknya literatur yang dapat diakses secara gratis. Artikel dipilih berdasarkan publikasi yang diterbitkan dalam periode waktu dari tahun 2016 sampai dengan tahun 2021.

Hasil: Posisi duduk yang tidak ergonomis, durasi duduk cukup lama dengan posisi yang sama, lingkungan kerja, dan karakteristik individu seperti umur, jenis kelamin, dan Indeks Massa Tubuh (IMT) berhubungan dengan kejadian LBP. Sementara itu, beban kerja tidak berhubungan dengan kejadian LBP.

Kesimpulan: Faktor yang mempengaruhi kejadian LBP pada pekerja kantoran yaitu karakteristik individu, posisi duduk, durasi duduk, dan faktor lingkungan kerja berhubungan dengan kejadian LBP. Sedangkan faktor yang tidak berhubungan yaitu beban kerja. Diharapkan kepada para pekerja kantoran untuk memperbaiki posisi dan durasi duduknya sebagai pencegahan terhadap LBP.
\end{abstract}

Kata kunci : Low Back Pain, posisi duduk, pekerja kantoran, dan tempat kerja

\section{Affected Factors of Low Back Pain Case in Office Workers: a Systematic Review}

\begin{abstract}
Background: The nerves of the lower waist often experience health problems which are currently better known as Low Back Pain (LBP), this disease is very common and became one of the main factors that affect the quality of work performance and welfare. The most common causes of Low Back Pain are sitting too long, the wrong sitting posture, and excessive activity. The purpose of this study were to identify and understand the major factors that cause LBP in the office workplace.

Methods: This study was processed through a systematic process which adapted to the Preferred Reporting Items for Systematic Review (PRISMA) stage. Google Scholar was used due to the convenience of accessing, the large amount of literature, and open access. Articles published during 2016 to 2021 were included.

Result: This study found that a non-ergonomic sitting position, long sitting duration in the same position, work environment, and individual characteristics (such as age, sex, and Body Mass Index (BMI)) were associated with the incidence of LBP. Meanwhile, the workload were not related to the incidence of LBP.

Conclusion: Individual characteristics, sitting position, sitting duration, and work environment were found as related factors of LBP. It is expected for office workers to improve their sitting position and duration as a prevention against $L B P$.
\end{abstract}

Key Words : Low Back Pain, sitting posture, office worker, and workplace

$\begin{array}{ll}\text { Korespondensi } & \text { : Veronica Christie Guesteva } \\ \text { Email } & \text { : veronicacg@upnvj.ac.id }\end{array}$




\section{PENDAHULUAN}

Menurut Global Burden of Disease tahun 2010 dalam duthey B. pada tahun 2014 Low Back Pain adalah salah satu penyakit dan cedera beban tertinggi, dengan jumlah rata-rata DALY (Disability-Adjusted Life Years) lebih tinggi daripada HIV, cedera di jalan, TB, kanker paru, penyakit paru obstruktif kronik dan komplikasi kelahiran prematur. ${ }^{1}$ Low Back Pain (LBP) merupakan salah satu masalah kesehatan yang berupa nyeri akut maupun kronik yang dirasakan di daerah punggung bawah dan biasanya merupakan nyeri lokal maupun nyeri radikular atau keduanya di daerah lumbosacral yang dapat disebabkan oleh inflamasi, degeneratif, kelainan ginekologi, trauma dan gangguan metabolik. ${ }^{2}$ Hal-hal yang berhubungan dengan pekerjaan, seperti beban kerja, posisi kerja dan repitisi merupakan beberapa penyebab Low Back Pain dapat terjadi. ${ }^{3}$

Berdasarkan data dari WHO pada tahun 2013 dalam Duthey B. pada tahun 2014 Low Back Pain tertinggi yaitu usia 4559 tahun yang penderitanya mencapai angka kurang lebih 9,1 juta dan usia 50-54 tahun dengan besar jumlah penderita 8,8 juta. Data ini menunjukkan bahwa rentang usia produktif merupakan risiko tinggi terkena Low Back Pain. Low Back Pain akan mengganggu keefektifan waktu dan kesehatan bagi para pekerja, Sehingga diperlukannya manajemen sumber daya manusia dan sistem kerja yang ergonomis untuk menurunkan angka penderita. ${ }^{1}$

Saat ini, Low Back Pain menjadi penyebab utama pembatasan aktivitas dan absen kerja. Tentunya hal ini dapat berdampak terhadap peningkatan beban ekonomi yang sangat besar pada individu, keluarga, komunitas, industri, dan pemerintah. Di Inggris, Low Back Pain diidentifikasi sebagai penyebab paling umum kecacatan pada orang dewasa dengan lebih dari 100 juta hari kerja hilang per tahun. Sementara itu, diperkirakan 149 juta hari kerja per tahun hilang karena Low Back Pain yang mengakibatkan kerugian antara US \$100 hingga US \$200 miliar per tahun di Amerika Serikat. ${ }^{4}$ Oleh karena itu penelitian ini bertujuan untuk memahami dan juga mengetahui berbagai faktor yang memiliki pengaruh terhadap kejadian Low Back Pain di tempat kerja.

\section{METODE}

Studi ini menggunakan metode kajian sistematik (systematic review). Kajian ini diolah melalui proses sistematik yang disesuaikan dengan tahapan Preferred Reporting Items for Systematic Review (PRISMA). Tahapan tersebut meliputi identifikasi, penyaringan, inklusi, dan kelayakan pada artikel atau jurnal yang diperoleh (Gambar 1.), untuk kemudian di analisis guna mendapatkan data mengenai Low Back Pain di tempat kerja.

Google Scholar menjadi salah satu pilihan peneliti karena kemudahan dalam mengakses juga banyaknya literatur yang dapat diakses secara gratis. Kata kunci yang ditentukan untuk menunjang pencarian, yaitu: Low Back Pain, Durasi Duduk, Beban Kerja, Posisi Duduk, Karakteristik Individu, Lingkungan Kerja, Tempat Kerja, Sitting Duration, Workload, Sitting Position, Individual Characteristics, Work Environment, dan Workplace. Setelah melakukan pencarian menggunakan kata kunci tersebut, peneliti perlu untuk menyeleksi kembali artikel berdasarkan publikasi yang diterbitkan dalam periode waktu dari tahun 2016 sampai dengan tahun 2021 (dalam rentang waktu 5 tahun) bertujuan agar sumber yang dipakai adalah jurnal relevan terbaru, diterbitkan dalam salah satu dari dua bahasa berikut, yaitu: Bahasa Inggris atau Bahasa Indonesia, keutuhan atau kesepadanan teks publikasi, memiliki relevansi dengan apa yang ingin dikaji peneliti, dan tentunya memiliki ISSN atau ISBN sebagai salah satu bukti kredibilitas. Kemudian dilakukan penyaringan kembali melalui penetapan kriteria inklusi responden seperti memiliki keluhan Low Back Pain dan hasil penelitian memiliki informasi yang bermanfaat pada bidang kesehatan. Kriteria eksklusi yang digunakan peneliti adalah sebagai berikut: ketidaklengkapan isi artikel dan tidak menggunakan dua bahasa yang menjadi kriteria inklusi, yaitu: Bahasa Inggris atau Bahasa Indonesia, artikel yang memiliki tahun terbit sebelum 2016, publikasi artikel yang tidak kredibel atau kurang jelas, hasil 
penelitian tidak memiliki dampak dalam bidang kesehatan dan yang terakhir tidak memiliki kredibilitas berupa ISSN atau ISBN.
Setelah tahap-tahap di atas, maka data akan disajikan dalam bentuk penjelasan naratif dan penarikan kesimpulan pada akhir kajian.

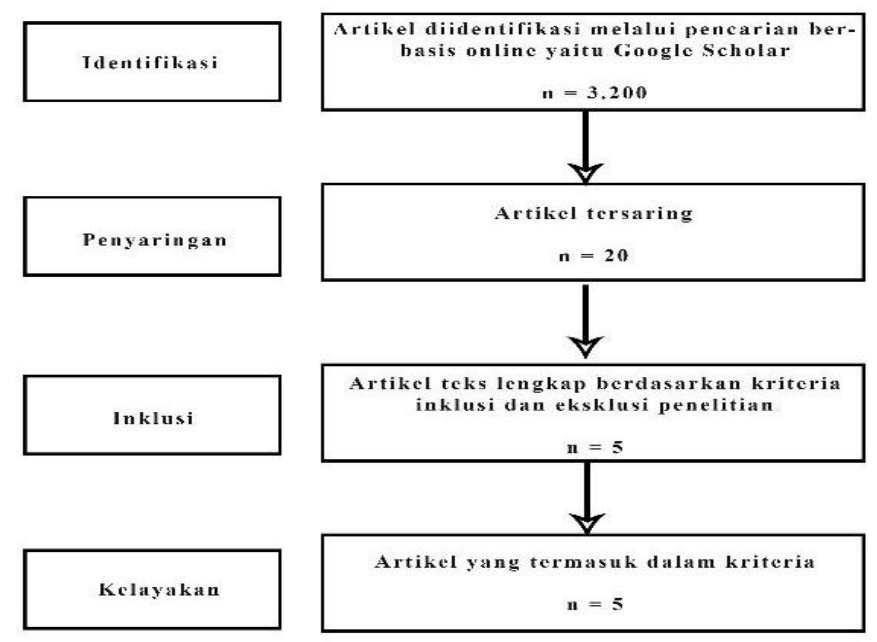

Gambar 1. Penghimpunan Artikel Memanfaatkan Metode PRISMA

HASIL

Dari 3200 publikasi yang teridentifikasi, hanya terdapat lima studi yang kami pilih sesuai dengan kriteria inklusi dan kelayakan. Studi tersebut dilakukan di 2 negara yaitu Indonesia dan Iran.

Dari kelima jurnal tersebut, didapatkan bahwa faktor-faktor penyebab keluhan Low Back Pain antara lain sikap duduk, posisi kerja, masa atau waktu kerja, gerakan berulang dan beban kerja. Pada systematic review ini, beban kerja tidak dimasukkan menjadi penyebab keluhan Low Back Pain karena subjek artikel saat ini adalah pekerja kantoran, sedangkan pada penelitian Kalantari $\mathrm{dkk}^{9}$ subjeknya ialah pekerja perusahaan manufaktur. Sementara itu, posisi kerja dan postur kerja tidak menyebabkan keluhan Low Back Pain.

\section{PEMBAHASAN}

Berdasarkan laporan penelitian yang sudah didapatkan, ditemukan beberapa hal yang dapat mempengaruhi kejadian Low Back Pain pada pekerja yaitu posisi duduk, durasi duduk, stress/beban kerja, karakteristik individu, dan faktor lingkungan.

\section{Hubungan Posisi Duduk dengan Kejadian Low Back Pain}

Posisi duduk yang tidak ergonomis saat bekerja berpengaruh pada kesehatan pekerja. Salah satunya dapat menimbulkan risiko cedera pada sistem muskuloskeletal. Berdasarkan tingkat risikonya, jenis postur duduk dikategorikan menjadi sedang, tinggi dan sangat tinggi. ${ }^{7}$ Risiko sangat tinggi mayoritas dialami oleh pekerjaan pengangkutan karena beban yang diangkat atau didorong secara manual dengan durasi sering. Risiko postur kerja sedang mayoritas dialami pada pekerja kantoran, karena mengangkat beban ringan atau kurang dari 5 $\mathrm{kg}$. Risiko yang bervariasi dapat muncul sebagai sebagai akibat beban yang diangkat selama bekerja juga berbeda-beda, ditinjau dari tugas hariannya. ${ }^{7}$

Terlalu lama duduk menyebabkan penambahan beban. Penambahan beban yang bersifat terus menerus, terlalu lama dan tidak segera tertangani dengan tepat dapat mengakibatkan gangguan yang berisiko menyebabkan kerusakan jaringan pada segmen vertebra, terutama segmen vertebra lumbalis. 
Tabel 1. Deskripsi Jurnal Hubungan Posisi Duduk di Tempat Kerja Terhadap Kejadian Low Back Pain pada Pekerja Kantora

\begin{tabular}{|c|c|c|c|c|c|c|}
\hline No & Penulis. Tahun. Judul & Tempat & $\begin{array}{l}\text { Jumlah } \\
\text { sampel }\end{array}$ & Metode & $\begin{array}{l}\text { Faktor } \\
\text { berkaitan } \\
\text { dengan LBP }\end{array}$ & Hasil dan kesimpulan \\
\hline 1 & $\begin{array}{lrr}\text { Aeni dan } & \text { Awaludin. } & \text { (2017). } \\
\text { "Hubungan Sikap Kerja } & \text { Duduk } \\
\text { Dengan Keluhan Nyeri Punggung } \\
\text { Bawah Pada Pekerja } & \text { Yang } \\
\text { Menggunakan Komputer." } & \end{array}$ & Indonesia & 59 & $\begin{array}{l}\text { Cross } \\
\text { Sectional }\end{array}$ & Sikap duduk & $\begin{array}{l}\text { Hasil penelitian ini menunjukkan bahwa sikap duduk saat bekerja } \\
\text { memiliki hubungan yang kuat }(\mathrm{p}=0.010) \text { dengan kejadian Low } \\
\text { Back Pain }\end{array}$ \\
\hline 2 & $\begin{array}{l}\text { Adha, Bahra, dan Mardhotila. (2020). } \\
\text { "Analisis Posisi Kerja menggunakan } \\
\text { Metode Ovako Working Analysis } \\
\text { System (OWAS) dan Kebiasaan } \\
\text { Olahraga Terhadap Keluhan Low } \\
\text { Back Pain." }\end{array}$ & Indonesia & 50 & $\begin{array}{l}\text { Cross } \\
\text { Sectional }\end{array}$ & Posisi kerja & $\begin{array}{l}\text { Hasil penelitian ini menunjukkan bahwa tidak ada hubungan } \\
\text { antara posisi kerja dengan keluhan Low Back Pain. }(\mathrm{p}=0,832)\end{array}$ \\
\hline 3 & $\begin{array}{l}\text { Rahmawati, Sudarmanto, dan Hasan. } \\
\text { (2019). "Risiko Postur Kerja Tidak } \\
\text { Mempengaruhi Indeks Disabilitas } \\
\text { Pekerja dengan Keluhan Low Back } \\
\text { Back Pain di PT Muroco Jember." }\end{array}$ & Indonesia & 31 & $\begin{array}{l}\text { Cross } \\
\text { Sectional }\end{array}$ & Postur kerja & $\begin{array}{l}\text { Penelitian ini menunjukkan bahwa tidak ada hubungan antara } \\
\text { risiko postur kerja dengan indeks disabilitas pekerja dengan } \\
\text { keluhan Low Back Pain di PT Muroco Jember }(\mathrm{p}=0,135)\end{array}$ \\
\hline 4 & $\begin{array}{l}\text { Efendi dan Hafiza. (2017). "Faktor } \\
\text { yang Berhubungan dengan Keluhan } \\
\text { Nyeri Punggung Bawah pada } \\
\text { Karyawan Redaksi Bagian Kantor di } \\
\text { PT. Riau Pos Intermedia } \\
\text { Pekanbaru."8 }\end{array}$ & Indonesia & 68 & $\begin{array}{l}\text { Cross } \\
\text { Sectional }\end{array}$ & $\begin{array}{l}\text { Masa kerja, } \\
\text { waktu kerja, } \\
\text { posisi kerja, dan } \\
\text { gerakan berulang }\end{array}$ & $\begin{array}{l}\text { Dari hasil penelitian yang telah dilakukan menunjukkan bahwa } \\
\text { ada } 3 \text { dari } 4 \text { variabel yang memiliki hubungan signifikan dengan } \\
\text { kejadian Low Back Pain, variabel tersebut diantaranya adalah } \\
\text { waktu kerja }(\mathrm{p}=0,008) \text {, masa kerja }(\mathrm{p}=0,049) \text { serta gerakan } \\
\text { berulang }(\mathrm{p}=0,016) \text {. Sedangkan satu variabel yaitu posisi kerja } \\
\text { tidak terdapat hubungan yang signifikan dengan keluhan Low } \\
\text { Back Pain }(\mathrm{p}=0,672) \text {. }\end{array}$ \\
\hline 5. & $\begin{array}{l}\text { Kalantari, dkk. (2016). "Relationship } \\
\text { between Workload and Low Back } \\
\text { Pain in Assembly Line Workers." } 9\end{array}$ & Iran & 69 & $\begin{array}{l}\text { Cross } \\
\text { Sectional }\end{array}$ & Beban kerja & $\begin{array}{l}\text { Menurut penelitian ini, disimpulkan bahwa terdapat hubungan } \\
\text { antara beban kerja dengan keluhan nyeri punggung bawah (nilai } \mathrm{p} \\
=0,037 \text { ). }\end{array}$ \\
\hline
\end{tabular}


Duduk lama meningkatkan kecenderungan berposisi duduk statis, yang mengakibatkan oksigenasi ke diskus, ligamentum, otototot, dan jaringan lainnya terganggu, sehingga timbul rasa nyeri atau tidak nyaman di area punggung bawah ${ }^{10}$

Hasil penelitian dengan menggunakan Metode Ovako Working Analysis System (OWAS) telah dilakukan oleh Adha dkk. Korelasi Spearman yang digunakan menunjukkan hubungan antara posisi kerja dengan keluhan Low Back Pain, korelasi tidak bermakna secara statistik dengan nilai $p$. Penelitian pada karyawan office di Badan Pengkajian dan Penerapan Teknologi (BPPT) tahun 2020 dengan menggunakan metode cross sectional menunjukkan bahwa posisi duduk tidak memiliki korelasi bermakna dengan keluhan Low Back Pain dengan nilai $\mathrm{p}=0,832 \quad(>0,05) .{ }^{6}$ Berbeda dengan hasil penelitian yang telah dilakukan oleh Kasumawati, dkk yang menunjukkan adanya hubungan antara posisi kerja terhadap keluhan Low Back. ${ }^{11}$

\section{Hubungan Durasi Duduk dengan Kejadian Low Back Pain}

Pekerja yang duduk dalam waktu lama dan statis dapat menyebabkan vertebralis terutama lumbar mengalami ketegangan. ${ }^{6}$ Oleh sebab itu, pekerja dituntut sesering mungkin mengubah posisi tubuhnya saat bekerja.

Durasi duduk yang cukup lama yang tidak diikuti dengan istirahat yang cukup dapat berdampak pada struktur tulang belakang akibat adanya proses biomekanika yang terjadi, terlebih duduk dengan tidak menggunakan sandaran. ${ }^{12}$ Ketika duduk, tekanan pada diskus intervertebralis akan timbul dua kali lebih besar dibandingkan dengan posisi berdiri. Jika rasa nyeri yang timbul dibiarkan terusmenerus, hal ini dapat menyebabkan kualitas hidup individu tersebut memburuk. Namun, keluhan ini tidaklah mutlak yang berarti keluhan di setiap individu akan berbeda karena perbedaan persepsi nyeri akibat adaptasi neuromuskuler di jaringan lunak tulang belakang, dimulai dari nyeri ringan hingga nyeri berat yang membutuhkan perlakuan khusus. ${ }^{12}$ Selain itu, duduk dengan durasi yang lama dapat menyebabkan beban berlebih pada otot pinggang yang apabila terjadi secara terus-menerus akan membuat pinggang menjadi lebih mudah lelah. Dan pada akhirnya memperbesar kemungkinan terjadinya kerusakan jaringan di vertebra sehingga muncullah nyeri pada otot. ${ }^{13}$

Menurut N.C. Department of Labor yang berada di Raleigh, Carolina Utara, Amerika Serikat, individu mampu bekerja dalam kurun waktu 8-10 jam, sehingga apabila melebihi durasi tersebut maka akan menurunkan efisiensi dan kualitas kerja. Duduk selama 2-4 jam di depan komputer saat bekerja atau belajar sudah cukup mampu menimbulkan rasa tidak nyaman di daerah punggung bagian bawah yang timbul karena durasi duduk yang cukup lama dan posisi duduk yang tidak tepat. Ketika duduk, karena pengaruh gravitasi, tubuh akan memberikan beban dan tekanan yang berlawanan arah namun sama besarnya. ${ }^{14}$ Tekanan tersebut berasal dari punggung, leher, lengan dan kaki yang dapat mempengaruhi kondisi fisik individu dan berdampak negatif pada otot punggung dan sistem tulang belakangnya. ${ }^{15}$

Hubungan lamanya duduk dengan kejadian Low Back Pain ini dapat dilihat dari penelitian terdahulu. Menurut penelitian yang dilakukan oleh Ratna Wardani ${ }^{16}$ di Kediri, lamanya duduk memiliki hubungan yang signifikan dengan kejadian nyeri pinggang (nilai $\mathrm{p}=0,003$ ). Sejalan dengan penelitian tersebut, penelitian Pirade $\mathrm{dkk}^{10}$ tahun 2013 juga menyatakan bahwa pekerja yang duduk statis selama 1,5-5 jam berpeluang 2,35 kali lebih besar mengalami Low Back Pain dibandingkan dengan pekerja yang duduk selama $<1,5$ jam. Begitu pula pada penelitian Sari $\mathrm{dkk}^{12}$, didapatkan nilai $\mathrm{p}$ sebesar 0.014 (nilai $\mathrm{p}<0.05$ ) yang dapat diartikan bahwa terdapat hubungan antara durasi duduk dengan keluhan Low Back Pain operator komputer jasa travel di Manado.

\section{Hubungan Beban Kerja dengan Kejadian Low Back Pain.}

Beban kerja dapat didefinisikan sebagai beberapa pekerjaan milik individu atau kelompok yang bersifat wajib untuk diselesaikan dalam periode tertentu yang dispesifikasikan pada setiap pekerjaan, tugas, dan individu. Tekanan kerja dan beban kerja yang berlebihan dapat mempengaruhi kesehatan. Faktanya, ketidak-seimbangan antara syarat pekerjaan dengan kemampuan pekerja dapat mengarah kepada Low Back Pain. ${ }^{9}$ Beban kerja berasal dari fisik, mental dan cara kerja. Cara bekerja dapat diatur agar otot tidak menjadi tegang, kelelahan berlebih 
atau gangguan kesehatan lainnya yang dapat timbul. ${ }^{5}$ Beban pekerjaan yang lebih besar daripada kemampuan pekerja dapat menimbulkan kelelahan, menurunnya kualitas kerja, sehingga mempengaruhi keselamatan dan kesehatan kerja. Beban kerja pada pekerja kantoran dalam penelitian ini dapat didefinisikan sebagai kuantitas pekerjaan yang dilakukan diluar kemampuan pekerja baik secara fisik maupun mental sehingga mempengaruhi kesehatan dan keselamatan kerja.

Dalam penelitian yang dilakukan oleh Kalantari, dkk pada tahun 2016 menunjukkan beban kerja baik secara fisik maupun mental berhubungan secara signifikan dengan kejadian Low Back Pain. ${ }^{9}$ Namun, penelitian tersebut dilakukan pada perusahaan manufaktur mobil sehingga tidak relevan dengan subjek penelitian saat ini yaitu pekerja kantoran.

Sebelumnya, telah dilakukan sejumlah penelitian $^{5-9}$, yang menghasilkan bahwa beban kerja tidak berhubungan secara signifikan dengan kejadian Low Back Pain. Namun, disebutkan oleh peneliti-peneliti ini bahwa kemungkinan terjadi bias alasan hubungan tidak signifikan ini karena indeks disabilitas pekerja yang tidak representatif. ${ }^{7}$ Indeks disabilitas pekerja merupakan suatu alat pengukur yang komprehensif untuk membantu perusahaan mengambil jalur tindakan yang terukur dan nyata agar mencapai inklusi dan kesetaraan disabilitas. Skor dalam indeks disabilitas pekerja dimulai pada skala 0-100, dengan ketentuan skala $>80$ dapat diakui sebagai tempat bekerja terbaik untuk penyandang inklusi disabilitas. Beban kerja berat yang dapat memicu kejadian Low Back Pain terjadi pada pekerja dengan media atau alat kerja yang tidak normal. Alat kerja yang tidak normal dimaksudkan dalam penelitian ini seperti penggunaan media komputer atau laptop untuk menunjang pekerjaan terjadi error sehingga pekerjaan harus tertunda. ${ }^{17}$ Selama media atau alat kerja diperbaiki, pekerja akan melakukan pekerjaannya secara manual sehingga beban kerja meningkat.

\section{Hubungan Karakteristik Individu dengan Kejadian Low Back Pain.}

Pada studi ini, karakteristik individu fokus berupa umur, jenis kelamin, dan Indeks Massa Tubuh (IMT) individu. Semakin tua seseorang maka semakin banyaknya penurunan fungsi tubuh yang dimana normal terjadi. Angka prevalensi pada orang dewasa meningkat dan memuncak antara usia 35 dan 55, dikarenakan pada usia tersebut berisiko penyakit seperti osteoporosis, neoplasma atau infeksi. ${ }^{1}$

Jenis kelamin dapat berhubungan dengan adanya kejadian Low Back Pain, seperti pada wanita yang seiringnya bertambah usia akan mengalami masa menopause, menyebabkan kepadatan tulang berkurang, sehingga sering terjadi adanya keluhan nyeri pinggang. ${ }^{18}$

Karakteristik yang ketiga, Indeks Massa Tubuh atau IMT seorang individu memiliki hubungan atau keterkaitan dengan kejadian Low Back Pain. Berdasarkan data dari penelitian yang menggunakan responden berupa mahasiswa Fakultas Kedokteran Universitas Udayana menemukan hasil dari 61 mahasiswa yang menyatakan memiliki keluhan Low Back Pain disebabkan oleh overweight sebanyak 35 orang. Nilai p sebesar $0,01 \quad(p<0,05)$, menunjukkan bahwa terdapat hubungan yang bermakna antara indeks massa tubuh kategori overweight dengan keluhan Low Back Pain pada mahasiswa Fakultas Kedokteran Universitas Udayana. ${ }^{19}$ Bagi individu dengan berat badan berlebih (overweight) beban pada tubuh bagian bawah dan tulang belakang akan bertambah, berdampak pada kelelahan otot akibat dari upaya otot untuk menopang beban berlebih. Penelitian lainnya yakni menggunakan responden berupa 80 pasien di RSUD Panembahan Senopati Bantul. ${ }^{20}$ Pada pasien kategori overweight didapatkan data sebesar 21 kejadian Low Back Pain akut (80,8\%) dan 5 kejadian Low Back Pain kronis (19,2\%). Berdasarkan hasil nilai $\mathrm{p}$ sebesar 0,036 (p < $0,05)$, disimpulkan terdapat hubungan antara IMT dengan kejadian Low Back Pain. ${ }^{20}$

\section{Hubungan Lingkungan Kerja dengan Kejadian Low Back Pain.}

Lingkungan kerja merupakan semua sarana maupun prasarana yang dapat memberikan efek pada individu yang bekerja di tempat tersebut. Lingkungan kerja dapat meliputi fasilitas di tempat kerja, alat bantu dalam melakukan pekerjaan, kebersihan tempat kerja, pencahayaan di tempat kerja dan hubungan dengan pekerja lainnya. Lingkungan kerja yang baik mampu memberi motivasi dan meningkatkan semangat para pekerja. 
Lingkungan kerja yang baik misalnya dengan pencahayaan yang cukup, lingkungan sekitar yang bersih dari sampah, ataupun dengan menambahkan fasilitas seperti Air Conditioner (AC) di ruang kerja. ${ }^{21}$

Lingkungan kerja harus memenuhi ketentuan Workplace (Health, Safety, and Welfare). Banyak bahaya kesehatan yang dapat ditimbulkan dari lingkungan kerja. Salah satu bentuk gangguan yang timbul pada pekerja di lingkungan perkantoran adalah Low Back Pain. ${ }^{22}$

Faktor lingkungan yang paling berpengaruh untuk kejadian Low Back Pain yaitu terlihat dari segi ergonomis, faktor mental dan psikologis serta kepuasan para pekerja di perusahaan tersebut. ${ }^{23}$

Pekerja yang tidak puas dengan pekerjaannya di tempat kerja karena masalah situasi sosial mempunyai angka kejadian Low Back Pain lebih tinggi. Menurut penelitian Bergenudd dan Nilsson pekerja yang tidak menikmati pekerjaan yang mereka lakukan, 2,5 kali lebih berisiko terkena Low Back Pain dibandingkan mereka yang menikmati pekerjaannya. Selain itu, ada juga karena ruang kerja yang kurang baik, beban kerja yang terlalu berat, hubungan yang tidak harmonis dengan atasan atau dengan karyawan lainnya, serta suasana kantor yang kurang menyenangkan dapat menjadi faktor risiko dari Low Back Pain. ${ }^{23}$

Selain itu ada juga hasil beberapa peneliti seperti Kerr, Erriksen dan van Poppel menyatakan bahwa faktor emosi dan kepuasan kerja dapat mempengaruhi kejadian Low Back Pain pada karyawan perusahaan. Penelitian dari Reene Shibukuwa juga menyebutkan bahwa karyawan yang mengalami stres kerja 4,93 lebih berisiko terkena Low Back Pain dibandingkan karyawan yang tidak mengalami stres kerja. ${ }^{24}$

\section{KESIMPULAN}

Posisi dan durasi duduk, karakteristik individu serta lingkungan kerja mempunyai hubungan yang signifikan terhadap kejadian Low Back Pain. Sementara itu, beban kerja tidak mempunyai hubungan yang signifikan terhadap kejadian Low Back Pain, namun media atau alat kerja yang tidak normal dapat memperbesar kemungkinan terjadinya Low Back Pain, seperti penggunaan media komputer atau laptop untuk menunjang pekerjaan terjadi error sehingga pekerjaan harus tertunda.

Melalui systematic review ini, diharapkan dapat memberikan saran kepada para pekerja untuk memperhatikan durasi duduk saat bekerja, melakukan peregangan otot tubuh saat mulai terasa penat, menerapkan posisi yang tepat di tempat duduk yang sudah diatur sesuai standar, dan menyesuaikan kemampuan fisik serta menerapkan cara bekerja yang sesuai sehingga tidak adanya beban kerja yang berlebihan yang dapat mengganggu kesehatan para pekerja. Saran untuk perusahaan yakni dapat melakukan kegiatan olahraga bersama secara rutin.

\section{DAFTAR PUSTAKA}

1. Duthey B. Background Paper Low Back Pain [Internet]. 2013. Available from:

https://www.who.int/medicines/areas/p riority_medicines/BP6_24LBP.pdf

2. Mahadewa TGB, Maliawan S. Diagnosis dan Tatalaksana Kegawatdaruratan Tulang Belakang [Internet]. Jakarta: Sagung Seto; 2009. Available from: https://scholar.google.co.id/citations?vi ew op=view citation $\& \mathrm{hl}=$ en\&user $=\mathrm{Fz}$ KEqh8AAAA J\&citation for view $=\mathrm{Fz}$ KEqh8AAAAJ:u5HHmVD_uO8C

3. Almoallim H, Alwafi S, Albazli K, Alotaibi M, Bazuhair T. A Simple Approach of Low Back Pain. Int J Clin Med. 2014;05(17):1087-98.

4. Kaplan W, Wirtz V, Mantel A, Béatrice P. Priority Medicines for Europe and the World Update 2013 [Internet]. Vol. 2, Methodology. 2013. Available from: https://www.who.int/medicines/areas/p riority_medicines/MasterDocJune28_F INAL_Web.pdf

5. Aeni HF, Awaludin A. Hubungan Sikap Kerja Duduk Dengan Keluhan Nyeri Punggung Bawah Pada Pekerja Yang Menggunakan Komputer. J Kesehat [Internet]. 2017;8(1):887-94. Available from: http://jurnal.stikescirebon.ac.id/index.p $\mathrm{hp} /$ kesehatan/article/view/92/41

6. Adha MZ, Bahri S, Mardhotila SY. 
Analisis Posisi Kerja menggunakan Metode Ovako Working Analysis System (OWAS) dan Kebiasaan Olahraga Terhadap Keluhan Low Back Pain (LBP). J Mhs Dan Penelit Kesehat. 2020;7(2):26-31.

7. Rahmawati A, Sudarmanto Y, Hasan M. Risiko Postur Kerja Tidak Mempengaruhi Indeks Disabilitas Pekerja dengan Keluhan Low Back Back Pain di PT Muroco Jember. J Agromedicine Med Sci [Internet]. 2019;5(1):7-12. Available from: https://pdfs.semanticscholar.org/6cae/d 8f9bacab78b96e2256701b6f6386d0f93 3e.pdf

8. Efendi AS, Sri H. Faktor Yang Berhubungan Dengan Keluhan Nyeri Punggung Bawah Pada Karyawan Redaksi Bagian Kantor Di Pt. Riau Pos Intermedia Pekanbaru. MENARA Ilmu [Internet]. 2017;XI(77):10-7. Available from:

https://jurnal.umsb.ac.id/index.php/men arailmu/article/view/322

9. Kalantari R, Arghami S, Ahmadi E, Garosi E, Farahani AZ. Relationship Between Workload and Low Back Pain in Assembly Line Workers. J Kermanshah Univ Med Sci. 2016;20(1):26-30.

10. Pirade A, Angliadi E, Sengkey LS. Hubungan Posisi Dan Lama Duduk Dengan Nyeri Punggung Bawah (Npb) Mekanik Kronik Pada Karyawan Bank. J Biomedik. 2013;5(1):98-104.

11. Kasumawati F, Adha MZ, Azizah FN, Ramuni K, Katta R. Correlation between length of work and work posture with low back pain complaint among back office employees at $\mathrm{X}$ Hospital Serpong District, South Tangerang, Indonesia. Malaysian J Med Heal Sci [Internet]. 2020;16(8):34-7. Available from: https://medic.upm.edu.my/upload/doku men/2020111315105306_MJMHS_027 4.pdf

12. Sari NPLNI, Mogi TI, Angliadi E. Hubungan Lama Duduk Dengan Kejadian Low Back Pain Pada
Operator Komputer Perusahaan Travel Di Manado. e-CliniC [Internet]. 2015;3(2):687-94. Available from: https://ejournal.unsrat.ac.id/index.php/e clinic/article/view/8602/8175

13. Robo W. Hubungan Lama Duduk Dengan Kejadian Low Back Pain pada Supir Bus di PO Puspa Jaya Cabang Yogyakarta [Internet]. Universitas 'Aisyiyah; 2019. Available from:

http://digilib2.unisayogya.ac.id/bitstrea $\mathrm{m} /$ handle/123456789/414/NASKAH

PUBLIKASI-201510301011-S1

FISIOTERAPI-WINDA

ROBO.pdf? sequence=1\&isAllowed=y\#: $\sim:$ text=Hasil Penelitian\%3A Hasil penelitian dengan, $0 \% 2 \mathrm{C} 000$ yang berarti hubungan signifikan.\&text=Bagi supi

14. Cherie Berry, Allen McNeely, Kevin Beauregard EG. A Guide to Office Safety and Health. NC Dep Labor [Internet]. 2008;1-8. Available from: https://files.nc.gov/ncdol/documents/fil es/IG_33_Office_Safety.pdf

15. Nur FH. HUBUNGAN LAMA DUDUK SAAT JAM KERJA DAN AKTIVITAS FISIK DENGAN KELUHAN NYERI PUNGGUNG BAWAH (LOW BACK PAIN) PADA KARYAWAN KANTOR TERPADU PONTIANAK TAHUN 2014 [Internet]. Universitas Tanjungpura; 2015. Available from: https://media.neliti.com/media/publicat ions/192866-ID-hubungan-lamaduduk-saat-jam-kerja-dan-a.pdf

16. Wardani R. Faktor-Faktor yang Berhubungan dengan Kejadian Nyeri Pinggang pada Operator Komputer Warnet di Kecamatan Mojokerto Kota Kediri. STIKes Surya Mitra Husada [Internet]. 2012; Available from: https://studylibid.com/doc/622617/fakt or---faktor-yang-berhubungan-dengankejadian

17. Pua TLC., Kawatu PA., Kapantow NH. Hubungan Antara Beban Kerja Fisik Dengan Kelelahan Kerja Pada Pekerja Bagian Operator Boiler Dan Turbin Di Pjbs Pembangkit Listrik Tenaga Uap 
Amurang. J Kesmas. 2020;9(1):143-9.

18. Rosari ET. HUBUNGAN POSISI DUDUK DAN KARAKTERISTIK INDIVIDU TERHADAP KELUHAN LOW BACK PAIN PADA KARYAWAN PENGGUNA KOMPUTER DI PDAM TIRTA ASASTA TAHUN 2019. Universitas Pembangunan Nasional Veteran Jakarta; 2019.

19. Negara KNDP, Wibawa A, Purnawati S. HUBUNGAN ANTARA INDEKS MASSA TUBUH (IMT) KATEGORI OVERWEIGHT DAN OBESITAS DENGAN KELUHAN LOW BACK PAIN (LBP) PADA MAHASISWA FAKULTAS KEDOKTERAN UNIVERSITAS UDAYANA. Maj Ilm Fisioter Indones [Internet]. 2015;3. Available from: http://download.garuda.ristekdikti.go.id /article.php?article $=1705250 \&$ val $=977$

\&title=THE HUBUNGAN ANTARA INDEKS MASSA TUBUH IMT KATEGORI OVERWEIGHT DAN OBESITAS DENGAN KELUHAN LOW BACK PAIN LBP PADA MAHASISWA FAKULTAS KEDOKTERAN UNIVERSITAS UDAYANA

20. Sari US. Hubungan Indeks Massa Tubuh Terhadap Kejadian Low Back Pain di RSUD Panembahan Senopati Bantul. Fak Ilmu Kesehat Progr Stud S1 Fisioter. 2019;2.

21. Chandra D, Setiawan R. Pengaruh Lingkungan Kerja dan Iklim Organisasi terhadap Semangat Kerja Karyawan Pt.diantri. Agora [Internet]. 2018;6(1). Available from: https://media.neliti.com/media/publicat ions/287082-pengaruh-lingkungankerja-dan-iklim-orga-0310fb7c.pdf
22. Zaman MK. Hubungan Beberapa Faktor dengan Keluhan Nyeri Punggung Bawah pada Karyawan Kantor. J Kesehat Komunitas [Internet]. 2014;2(4):163-7. Available from: https://jurnal.htp.ac.id/index.php/kesko $\mathrm{m} /$ article/view/66/53

23. Saputra A. Hubungan Usia, Sikap Kerja, Dan Masa Kerja Dengan Keluhan Low Back Pain (LBP) Pada Pengrajin Batik Di Batik Semarang 16 [Internet]. UNIVERSITAS NEGERI SEMARANG 2020; 2020. Available from:

http://lib.unnes.ac.id/38945/1/6411415 149.pdf

24. Basuki K. Faktor Risiko Kejadian Low Back Pain Pada Operator Tambang Sebuah Perusahaan Tambang Nickel Di Sulawesi Selatan. Fakt Risiko Kejadian Low Back Pain Pada Oper Tambang Sebuah Perusah Tambang Nickel Di Sulawesi Selatan [Internet]. 2009;4(2):115-21. Available from: https://ejournal.undip.ac.id/index.php/j pki/article/view/2346/2068 